\title{
NEW SERIES
}

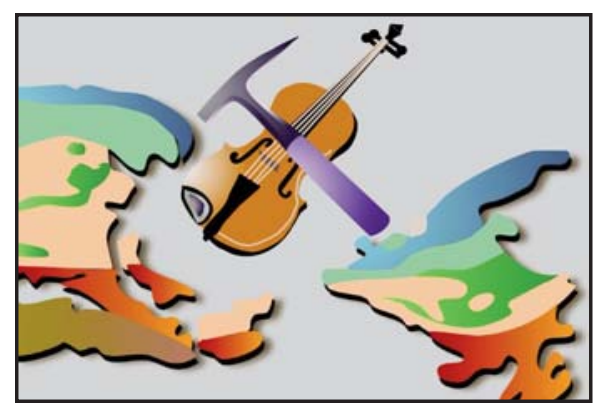

\section{Prologue: Harold Williams Series, Geoscience Canada}

This special issue of Geoscience Cana$\mathrm{da}$ is a memorial dedicated to the life and geological career of Harold Williams. In light of Hank's understated passion for field geology and regional synthesis, as well as the widereaching impact of his research, beyond the confines of Canada, it is fitting that Geoscience Canada issues a special series of papers in his honour. The series represents a collection of papers by authors who either worked with or knew Hank in some capacity and/or who capture his spirit and interests in their research. Once the series is complete, the papers will be published collectively in hard copy as a Geological Association of Canada Special Paper.

For those not acquainted with him, Harold 'Hank' Williams, FRSC

(March 14, 1934-September 28, 2010) was a premier Canadian field geologist known worldwide for his keen ability to glean critical relationships from the rock record and compile these data into meaningful regional syntheses; he packaged these talents with both an unforgettable personality and notable musical talent.

Hank was born in St. John's, Newfoundland, where he grew up in its rough and tumble Southside Hills section. He received his BSc (1956) and MSc (1958) at Memorial University of Newfoundland and proceeded to earn his PhD (1961) from the University of Toronto. He joined the Geological Survey of Canada in 1961 and built a strong reputation for field geology and regional synthesis. It was during his tenure at the survey that he penned one of his most influential scientific papers, The Appalachians in northeastern Newfoundland: A two-sided symmetrical system, which appeared in the American Journal of Science in 1964. A paper that was to influence one of his former mentors, J. Tuzo Wilson to ask the question "Did the Atlantic Ocean close and then re-open?' in the title of a Nature article in 1966.

In 1968 Hank accompanied

Ward Neale to the small geology department at his alma mater, Memorial University. While helping Ward forge a world-class geology department, Hank proceeded to create an impressive scientific career, accumulating numerous awards and medals and many 'first recipient' accolades. Perhaps his most recognized contribution to our science is his 1978 Tectonic Lithofacies Map of the Appalachian Orogen, a colorful, 11' long landmark map that was the first to bring into focus all of the first order attributes of this classic mountain belt. It is truly difficult to miss when unfurled on any wall, or in at least one reported case, a bedroom ceiling.
As a scientist of global renown, he is best remembered by the geological community for his acute observational abilities, his unique insights in synthesizing regional geology, and for his reserved, mischievous, and compassionate personality. As well, he is remembered by a much broader social spectrum for his down to earth wit, common sense, and ability to play multiple stringed instruments and the tin whistle (for a more complete recounting of his career, see Neale 1995).

To provide a more complete insight into Hank's life and career, we include here a few remembrances of the man in photographs and written word; the latter by those who had worked closely with him, including Michael J. 'Ben' Kennedy, Ron Smyth, John Dewey, and Jim Hibbard. We conclude this prologue with a short poem, The Master of Iapetus, written by Newfoundland poet, playwright, musician, and actor Des Walsh in honour of Hank on the $30^{\text {th }}$ anniversary of his map, the Tectonic-Lithofacies of the Appalachian Orogen.

Guest editors for the Harold Williams Series: Jim Hibbard, John Greenough, Brendan Murphy, Jeff Pollock, and Cees van Staal.

\section{ACKNOWLEDGEMENTS}

Many people deserve recognition for bringing this series to fruition. Cindy Murphy is thanked for her guidance through the Geoscience Canada system and for cheerfully keeping us organized and on track through the production of the series. We are grateful to Frank Blackwood, Peter Cawood, Lawson 
Dickson, J. Wright Horton, Brian O'Brien, and Andy Kerr for providing photos of Hank. Thanks to Des Walsh for permission to reproduce his poem herein. We also thank the many reviewers who conscientiously refereed the manuscripts we received and helped to improve the quality of the series; those who wish to be identified are named in the individual papers.

James Hibbard

Associate Editor

\section{REFERENCES}

Neale, E.R.W., 1995, An appreciation: Hank Williams - meticulous scientist wielding a broad brush, in Hibbard, J.P., van Staal, C.R., and Cawood, P.A., eds., Current Perspectives in the Appalachian-Caledonian Orogen, Geological Association of Canada Special Paper, v. 41, p. ix-xx.

\section{REMEMBRANCES}

The late Michael J. 'Ben' Kennedy was a faculty member at Memorial University of Newfoundland, his tenure overlapping with that of Hank's.

Hank [Harold] was born on March 14, 1934, in St John's Newfoundland. He entered Memorial University of Newfoundland where the Geology Department was then headed by David Baird, who clearly recognized his talents. $\mathrm{He}$ graduated with a BSc in 1956 and an MSc in 1958. He then went on to the University of Toronto where he obtained his $\mathrm{PhD}$ in 1961 under the supervision of J. Tuzo Wilson. Apart from his well-recognized geological talents he was an accomplished selftaught musician not only on the fiddle but also on the banjo and guitar and I have even heard him play the jew's harp. He was known as Hank for most of his career in recognition of musicianship. He had a quick wit and a real Newfoundland sense of humour. On meeting my twin sister his first remark was "You are better looking than your brother." He was known among a small group of colleagues for exploding with laughter at sometimes inappropriate junctures. He joined the Geological Survey of Canada in 1961. I first met him in Ireland in 1966 when he was visiting with Marshall Kay, who was then working in Newfoundland out of
Columbia University in New York. I gave them a tour of some of my rocks and took Hank to a famous music pub near Dublin one evening. We met up later that year in Newfoundland when I joined the GSC as an NRC postdoctoral fellow working on the Fleur de Lys Supergroup. We spent several days in the field together. 1967 was the year of the Gander Conference on Continental Drift in the North Atlantic, which was convened by Marshall Kay and where Hank unveiled his geological map of Newfoundland which was published by the GSC. This really revealed Hank's talents as a map compiler. His strategy each summer was to set up his field party, get them traversing and start visiting other areas where he thought important relationships could be found. He would return to his party regularly to assess progress and concentrate on important aspects that were emerging. In this way each map sheet was submitted on schedule and he emerged as by far the most productive member of the Appalachian Section. This outstanding ability to see the wood for the trees was recognized by Ward Neale, who was Head of the Appalachian Section from 1954 to 1966 and became a close friend. I joined Memorial University in 1967 and was surprised to get a phone call from Ward in 1968 to say he was coming to St John's and wanted to talk. It transpired that he had been asked to become the new Head of Geology by the President to develop the Department as a leading department in Cana$\mathrm{da}$, and I had to go up to Ottawa to persuade Hank to move to Memorial. Ward would not go unless Hank went too. We were successful and both arrived in St John's in the fall of that year. The rest is history. I left Memorial in 1976. Hank and I became close friends over those years and I learnt an awful lot from him, particularly how to see through the 'bullshit'. We got into several scrapes together, on occasions with Ward Neale as well. He had a seminal influence on many geologists including his graduate students as well as me. It is appropriate that this volume is dedicated to Hank [Harold] Williams: Appalachian Geologist par excellence.

Michael J. [Ben] Kennedy
Dublin Ireland

May 18, 2013

Dr. Ron Smyth was the first graduate student granted a $\mathrm{PhD}$ at the revitalized Department of Geology at Memorial University of Newfoundland (MUN).

We students knew him as Hank, not Dr. Harold Williams, nor Professor Williams, but just Hank. But we all knew he held these titles and that he was the greatest Appalachian geologist of our day. Hank had many passions; geology, field work, map making, playing Newfoundland music, storytelling, and having a good time with an occasional glass of dark rum. These passions combined to make a unique character that many were privileged to know and some of us were privileged to study under, to learn from, and be inspired by. He charmed those who met him. All who knew him will recall with smiles the colour and passion he brought to geology. Hank left the Geological Survey of Canada in 1968 at the height of his survey career to move back to Newfoundland with his friend, mentor and boss, Ward Neale, to take the position of Professor of Geology at Memorial University of Newfoundland. Ward had just been appointed Head of the Department.

I arrived in St. John's as a novice graduate student a few weeks later to study under Ben Kennedy who had taken a position at MUN a year earlier. My graduate committee was composed of Ben, Hank and Ward and what characters they were.

Hank personally mapped over half of the island of Newfoundland focusing on the Central Mobile Belt. In 1967 he published a modern compilation map of the Island and concurrently published a paper on the geological symmetry on the rocks of the Island just as the theory of plate tectonics was gaining global credence. His map and paper contributed to J. Tuzo Wilson's seminal paper in 1966 "Did the Atlantic Ocean Close and Reopen?." Hank realized that to expand on this hypothesis he needed to extend his mapping and knowledge of Appalachian geology to the two borderlands of his beloved central Newfoundland and ultimately along the entire length of 

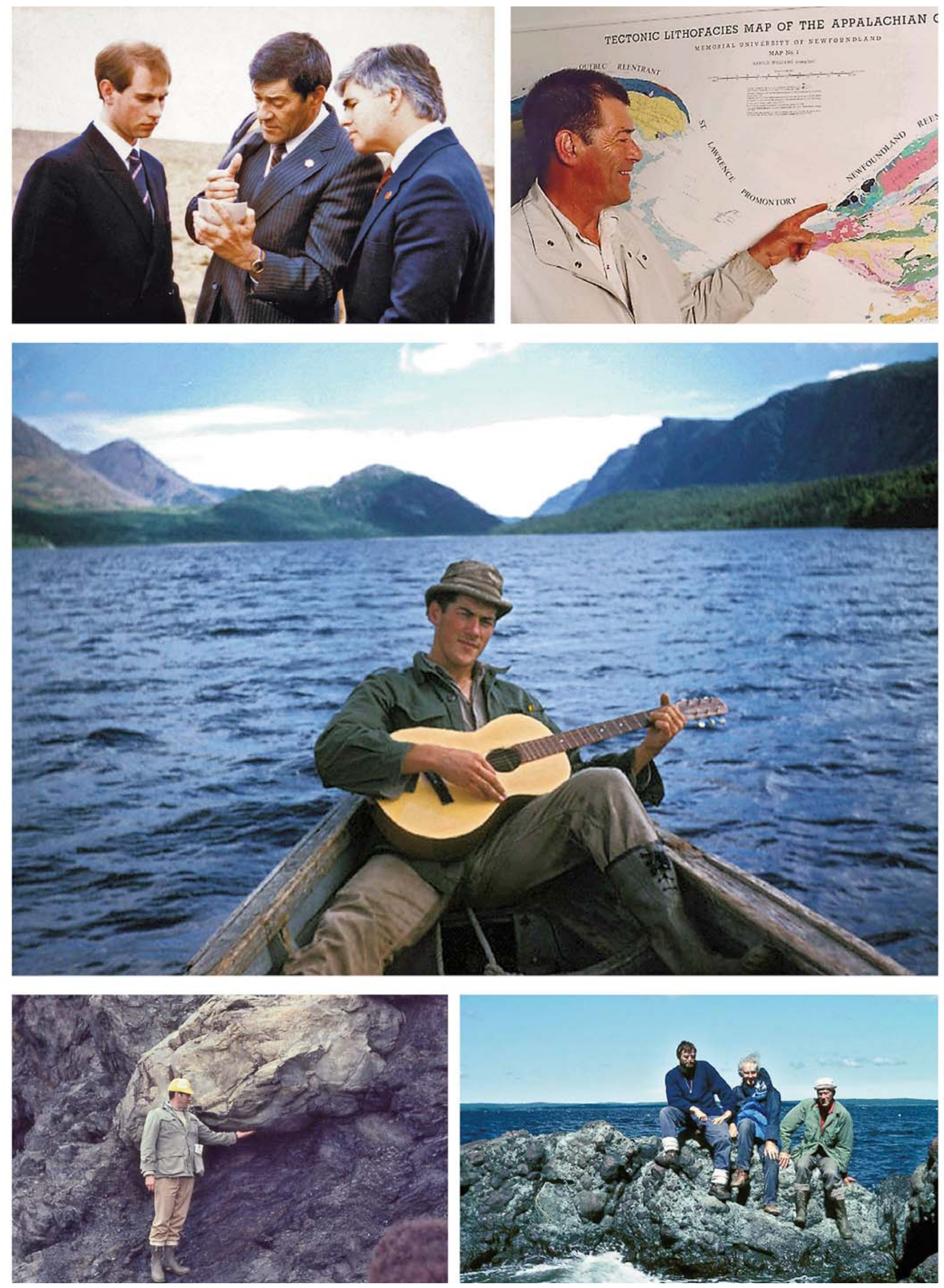

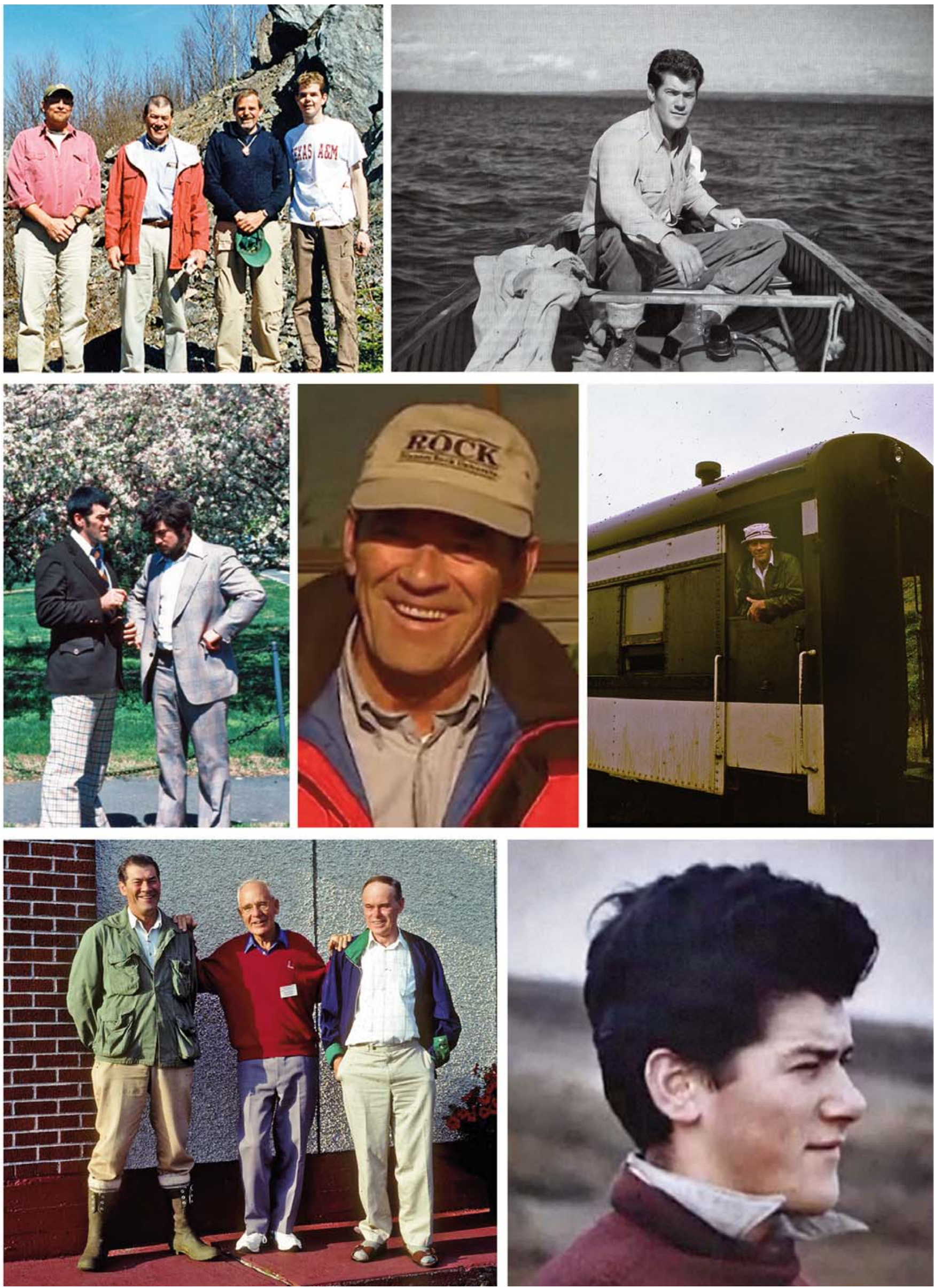
the mountain chain. So my committee enthusiastically steered me to study the Hare Bay Allochthon on the western borderland. I was trained in mapping at Irish farmer field scale and set about mapping coastal sections of Hare Bay at this scale. When Hank visited me later in the first year of my project he covered in a day what had taken me a month and he had creamed all the first order geological elements. On leaving Hank said "good work but pick it up a bit."

As the mysteries of the Hare Bay Allochthon unravelled Hank was keen to step offshore and map the adjacent Grey Islands. The islands were projected to be underlain by Ben Kennedy's Fleur de Lys Supergroup rocks and he commandeered Ben and me on the project. After a 3 hour crossing in open boats we arrived at the abandoned hamlet of Grey Island, found a house to make our camp, and settled on our mapping tasks; Ben and I would map the northern isle and Hank the southern. After 2 days Hank was finished, we on the other hand had only covered half of our isle. "Pick it up boys" said Hank as he departed! Ward Neale was a master at fund raising and never missed an opportunity to send his faculty and students off the rock to extoll the latest geological discoveries that were being made each field season from Ediacaran fossils, sheeted dykes and mantle rocks, the ancient Moho, island arcs, obducted ophiolites, giant submarine slump deposits, fossil subduction zones marked by thick mélange sequences, and in the process to recruit new graduate students. Hank was a sparkling conversationalist and lecturer. $\mathrm{He}$ coined the colourful term 'knockers' to describe exotic blocks contained in mélange: a term that never made it into the American Geoscience Dictionary of Geological Terms! Legends abound of late night parties at these conferences with singing 'dwarf lines', all spurred on by Hank's captivating banjo playing.

The GSC contracted Hank to help complete the last unmapped 1:250 000 scale map sheet on the islandthe St. Anthony Map which included my thesis area. Hank hired me to assist and I flew up to St. Anthony to meet up with Hank and his faithful boat- man. He had rented a house in Goose Cove as our base camp; however, it had no plumbing. My bedroom was being used as a commode with dozens of empty Dominion Ale bottles as the receptacles. It took some gall to get Hank to dispose of them. My next challenge was when Hank laid out our mapping assignments. I was assigned all of the inland traverses whilst Hank would map all of the coastal sections from the comfort of his Fogo Island skiff. After some negotiations we agreed to split the tasks; I would start on the inland work and Hank the coastal mapping. I required a float plane to set up a fly camp at a lake on the top of the White Hills ophiolite. The only plane in town was owned by the Sir William Grenfell Mission and Hank dispatched me to charter their plane which was used for medevac's along the southern Labrador coast. When I came back empty handed "no you cannot have our plane, what if we had a medical emergency" - Hank castigated me and told me I had gone about it all wrong. "Go and buy a case of rum, take it to pilot and arrange the charter." Of course the rum currency worked like a charm and the flight was on! Next I needed a canoe and camping gear. No bother, off we drove to a barn on a farm near Deer Lake. Inside was enough camping gear for a small army. Help yourself says Hank whilst he and the farmer conducted their business over some lubricating currency. Hank later allowed that he was storing the gear for the GSC and that it was cheaper and more efficient to keep it on the island than ship it back to Ottawa. To keep his managers happy it was declared as "lost overboard from canoe." When I returned from mapping the White Hills I discovered that Hank had left. His note informed me that his coastal work had gone so well that he mapped my part of the coast as well and that my inland work was so good that no more traverses were required! Our understanding of the association between obducted ophiolites and their underlying dynamo-thermal metamorphic aureoles was now gelling and resulted in a joint paper in 1973. Hank's big picture thinking is evident in the paper. He directed me to research the spatial association of metamorphic and ultramafic rocks from the Appalachians to the Caledonides and we generously reinterpreted the geology of unseen distant lands to accord with our model; that the aureoles resulted from the obduction of hot mantle rocks over sea floor volcanics.

Hank was now the dominant figure in Appalachian geology. This was gained from a wealth of field mapping, research and a sharp analytical mind. His true passion and genius was map-making. Hank could always see the big picture and it was this ability that allowed him to compile the superb 'Tectonic-Lithofacies Map' of the entire Appalachians from Alabama to Newfoundland and to help make the assembly of this complex mountain belt comprehensible. He coined the term 'Harry Hibb's effect', after the great Newfoundland accordion player, to provide a colourful explanation of the Wilson cycle.

It became time for me to leave the fertile and comfortable academic environment and earn a living. For the next nine years I lived and worked in St. John's and on occasion would run into my mentor and he would regale me with such stories of how he secured the funds to publish his Appalachian map, of storing 10,000 copies on the living room floor of his house because there was no room in the Department, and of having to buy floor jacks in an emergency to shore up the floor from possible collapse from the weight of the maps.

I, like all of Hank's students, feel so fortunate to have studied under an inspirational teacher and an intellectual whirlwind. He taught us so much about rocks but also about life, and about the power of a smile and a laugh in defusing tricky situations. And of course, in life, "pick up the pace boy, get that hair out, lard thundering." If the big fella in the sky needs some mapping done he now has the lad to do it. Hank is survived by his wife Jean and sons Sandy, David and Stephen. Along with them we miss Hank Williams and remember him fondly.

Ron Smyth Victoria, British Columbia June 5, 2013

John F. Dewey first crossed paths 
with Hank on a field trip in Newfoundland, also attended by many other notable geologists of the day; later, he assumed the position of visiting professor for a year at the Department of Geology at Memorial University of Newfoundland while Hank was there.

Hank remained, to the end, a true, robust, and loyal Newfoundlander, wizard musician, master of small boats, and great working field geologist. $\mathrm{He}$ told me that, growing up in St. John's during World War II, he and his friends, to make a little much-needed money, sold bits and pieces, booze, fags, and sundry trinkets to the sailors who came into St John's Harbour on the regular Atlantic convoys. On one of the destroyers, a young officer, Stuart McKerrow, who was to become the great Scottish geologist, was achieving fame with his senior officers for his uncanny cleverness in breaking German codes and in finding and destroying U-boats for which he was awarded the Distinguished Service Cross. Stuart died in 2002 but remembered the scruffy urchins with their persistent sales techniques who inhabited the St John's docks upon the arrival of a convoy ship, one of whom played the tin whistle and had a particularly persuasive sales line. Both Hank and Stuart, when I introduced them in Newfoundland in 1966, were convinced that they had met and conducted business on the docks in the 1940's. Whether true or not, this illustrates the organized entrepreneurship that characterized Hank's professional life. Everything that he did, in his geology and music, was done with a wry smile and extraordinary efficiency. During his career in the Geological Survey of Canada and Memorial University, he became a brilliant field geologist and regional synthesizer (working mostly in Newfoundland), lecturer, colleague, and supervisor and mentor of students. He probably cut and walked more bush lines than anyone else on Earth, and, seemingly effortlessly, wrote a stream of papers on the regional geology of Newfoundland that all cut through to the heart of an argument using detailed field observations to solve a regional geological problem.

His tipples, in moderation, were mainly beer (Black Horse \{arse\} and Dominion Ale) and Lamb's 120

Proof Navy Rum. I first met Hank in Baie Verte in 1965 during a splendid western Newfoundland field trip with Ward Neale, John Rodgers, Phil King, Lou Pavlides, and many other distinguished American and Canadian geologists. After the trip, Hank drove me back to St. John's showing me over four days the geology en route. Just to the east of Grand Falls, Hank pulled over by a bridge across a river with the remark that he was getting thirsty, a condition with which I agreed. He went back to the bridge, located a stout attached to a taught string and hauled in a cold six-pack of 'Black arse', four of which we consumed. This was repeated five times during the five days en route to St. John's. Hank knew how to plan! Before arriving 'to' St John's, we turned right along the Burin Peninsula, I thought to examine the geology. Upon arriving at a small outport on the southern tip, we jumped into Hank's boat and headed out to sea. I did not question our destination until we were several hours out. Hank's terse response was "I'm clear out of rum and need to stock up." We arrived in Saint Pierre \& Miquelon, stocked up, and spent two delightful days drinking with Hank's Gendarmerie friends before returning to the Burin and driving to St. John's.

In St. John's, Hank introduced me to many of his old mates and the fledgling Memorial Geology Department with Bob Stevens and Werner Brueckner, which I had visited with Marshall Kay in 1964. I badly needed a haircut; Hank took me to his favourite barber. I was very tired and dozed; the barber 'inflicted' a number one to Hank's great encouragement and amusement. Upon remonstrating with him, he said "now you look normal but, by the Lard Jaysus, you still talk. funny."

Later in the summer of 1965, Hank and Marshall Kay came to stay with me to look at the geology of western Ireland with Ben Kennedy. This was a memorable and joyous geological and musical trip in which we examined outcrops, argued about Ireland/Newfoundland correlations, played, sang, and drank. Naturally, Hank made many friends in Mayo and Galway with whom he corresponded for many years.

I remember, mostly, the happy and productive days that we spent together in the late 60's in Notre Dame Bay mapping and arguing about the Dunnage mélange, the Coaker porphyry, ridge subduction, the Silurian, and subduction-accretion. I came to stand in awe of Hank's skills with both wooden boats with a 'one-lunger' and the sleeker variety with a powerful outboard motor. On densely-foggy days, Hank would, unerringly, take us many miles through runs, tickles and bights to a precise locality. After two months though, I did get tired of seal flipper, stuffed squid, fish and brewis, and cod tongues, and, especially, Newfoundland boiled dinner.

Hank was a wonderful companion, raconteur, and musical entertainer, yet who retained a slightly shy inner persona. He was a brilliant outcrop observer who synthesized up to the regional Appalachian/Caledonian scale, culminating in his Appalachian tectonic maps. His deep understanding of geology and the way in which the Earth works through the observation of rocks in the field is becoming increasingly rare. Hank is mourned by all his friends for his friendship, humanity and insights.

John Dewey,

Oxford, UK

August 10, 2013

Jim Hibbard was Hank's MS student in the early 1970's and was hired for a year by Hank to assist in the compilation of the Tectonic Lithofacies Map of the Appalachian Orogen.

In 1973, as a new graduate student in my first semester in the Department of Geology at Memorial University of Newfoundland, I had become disillusioned with my original plans for study and I was strongly contemplating leaving grad school. At the time I was a long-haired, scruffy bearded, jeanswith-patches hippy. Evidently, the faculty had picked up on my vibes; one faculty member who I didn't know, dressed in a plaid jacket, white shirt and tie, with a point of dark hair projecting onto the center of his forehead from his otherwise short hairline came up to me in the hallway and came out 

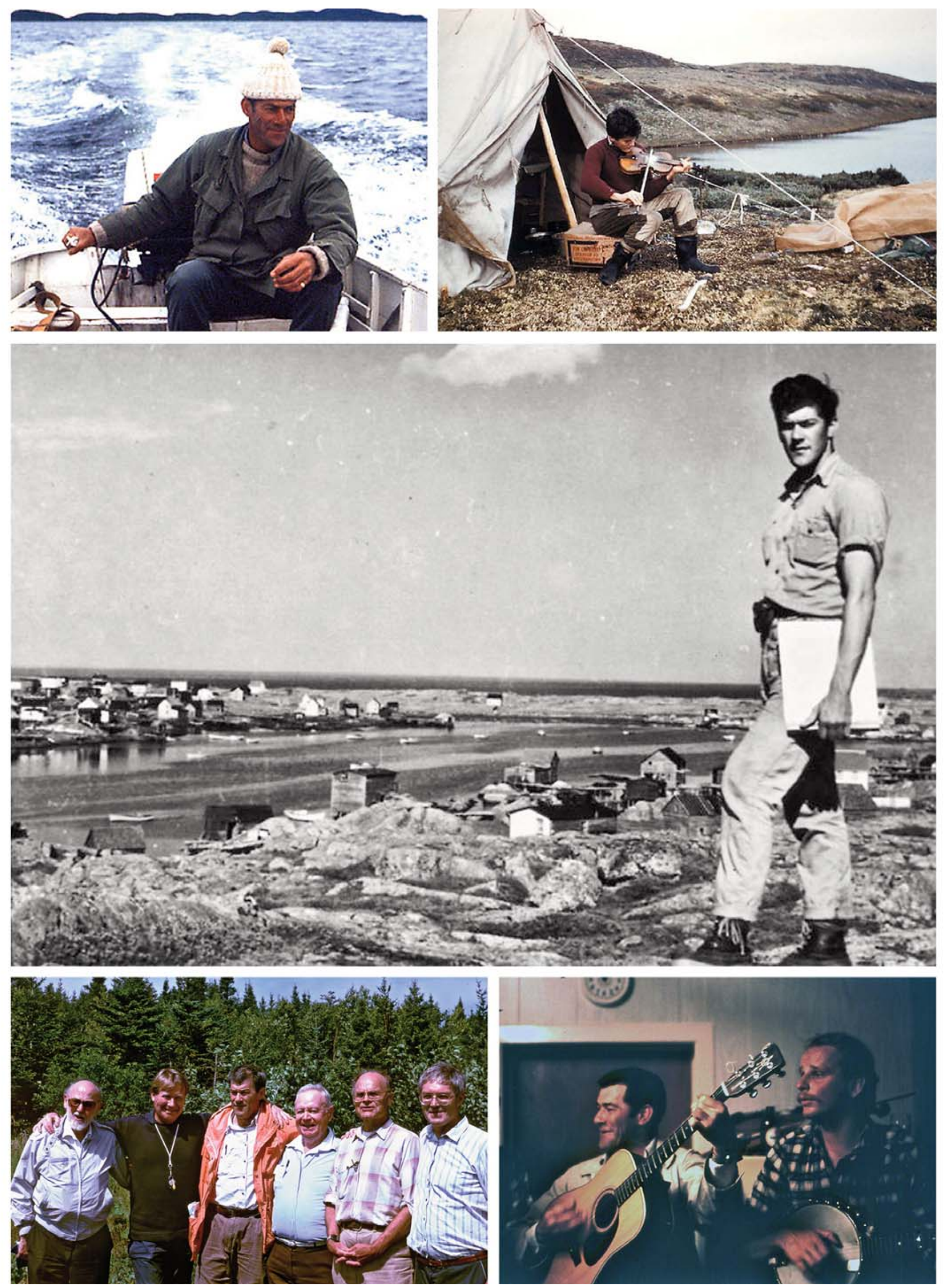

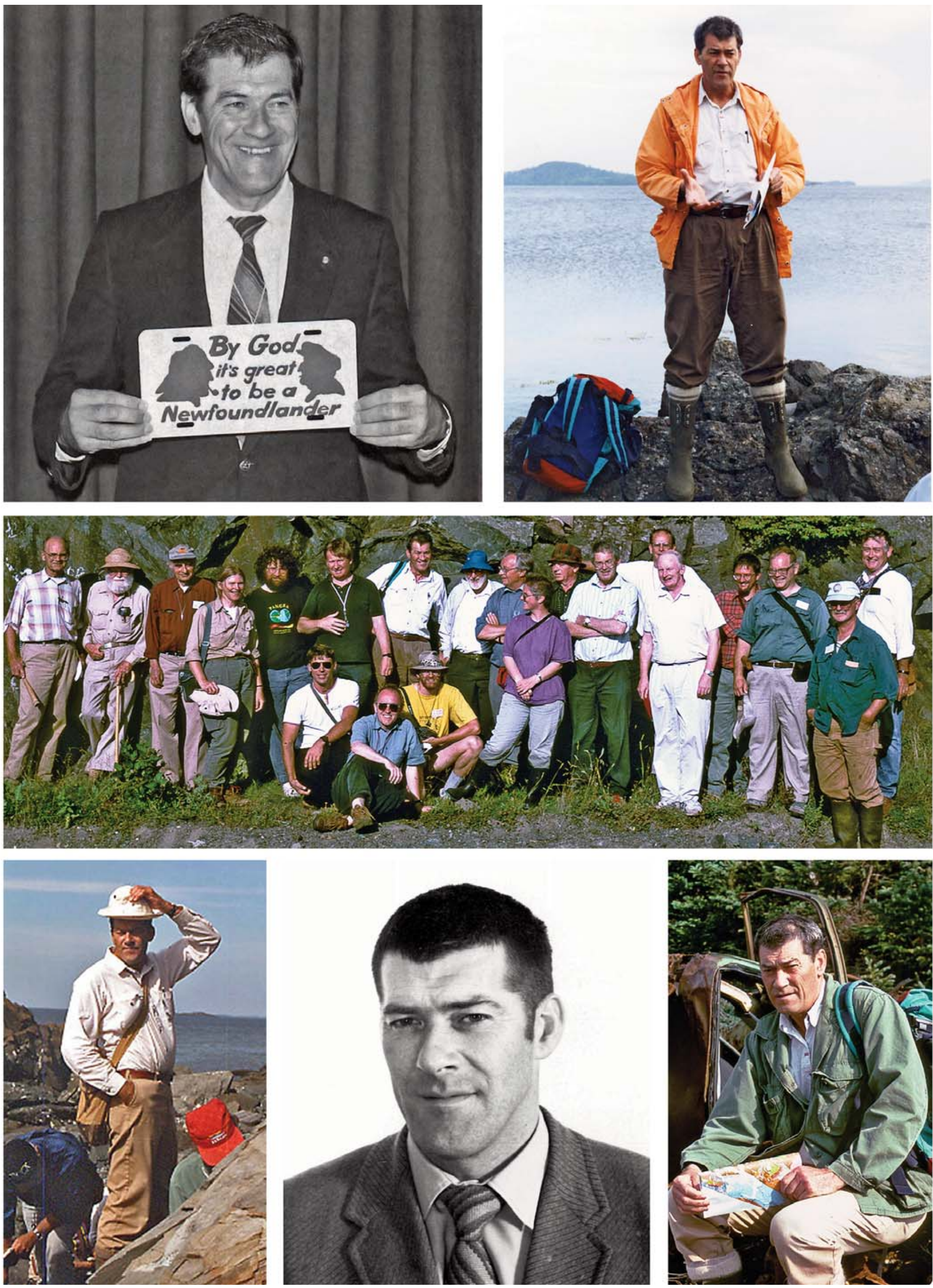
with "Are you Hibbard?" After affirming his question, the next thing I knew Hank had invited me to his house where his wife Jean served us a lunch of bottled moose and assorted unidentified Newfoundland 'edibles'. Before lunch was over, I had agreed to give grad school more time and to work with him on a project of my choice. We couldn't have been two more opposite people - but it worked. Little did I know that I was embarking on not only a new direction - investigating the Dunnage Mélange, but a lifelong career in Appalachian tectonics; all thanks to his interest in an unsettled student.

I recall Hank's first visit in the field - he badgered me about getting a haircut. I asked him what it mattered and his reply was practical - not having to take care of hair saves time in the morning - you can sleep longer and get going sooner. I was soon sporting shorter hair. It was then that he also set out to turn me into a Newfoundlander, despite my quiet reminders that, by birth, I did not qualify for the job. In the words of a later MS student of his, Chris Lee, who also experienced the same persistent attempts at conversion, "I might not make a Newfoundlander, but after working with Hank, I certainly know what one looks like." It was also during that first field season that I learned that Hank liked fresh salmon breakfast, lunch, and supper, seven days a week!

Hank taught largely by doing, not by consciously expounding. I learned a lot of field geology just by being his boatman for a summer and watching how he approached outcrops and the questions he asked about the rocks. I remember one calm day we were a good distance off the mouth of Ming's Bight, in the open North Atlantic when we noticed a disturbance on the water as a low swell gently rose and fell. Going over to investigate, we found that it was a sunker (barely submerged rock) of coarse peridotite less than a metre beneath the surface of the water, with dimensions just large enough to stand on as it plunged away on all sides into the black abyss. Hank sent the order "Hibbard bye, roll up your 'ti rubbers' (thigh rubbers - boots commonly worn while doing work on the ocean) and step out onto it?' It was then that I learned to identify the glittering bastites without putting a hand lens to the outcrop.

As part of my induction into Newfoundland culture Hank also introduced me to many of his childhood friends as well as to the legion in Kelligrews. We made many weekend trips to play music at different places in and around St. John's, and these visits almost invariably ended up at the house of one or another of Hank's childhood friends. One memorable invite was to a filling Jigg's dinner at the home of Gerald D. Doyle (accordion player) in Cape Broyle that culminated with an unlikely dessert of baked turr (a local seabird). Visits to the legion in Kelligrew's often ended at Bruce Tilley's house (Bruce's father had taught Hank and Bruce how to play fiddle) for a late night scoff of moose, salmon, lobster or whatever was available. During one visit to the legion with a dozen or so musicians and singers it came time for Hank to buy a round. Conscientiously he took everyone's order - this one a Black Horse, that one a Jockey Club, someone else an Old Stock, and so on; after all had made their request, Hank went around the table and perfectly repeated everyone's order. A few minutes later, he arrived back at the table with a big grin and a dozen Dominion Ales (his brand) on a tray. This episode demonstrated that Hank, confronted with multiple details, absorbed the data and synthesized the overriding truth of the situation - in this case, that we would drink anything. And so it was with his geological syntheses, he noted and knew the trees, but he never lost sight of the forest. Hank is missed by the geological community, especially by students who experienced his humility, generosity, compassion, and knack for having a good time at anything he did.

Jim Hibbard

Raleigh, North Carolina November 18, 2013

\section{The Master of Iapetus (for Hank Williams)}

“. .we find no vestige of a beginning, no prospect of an end..."

James Hutton 1726-1797

That noted gentleman farmer found granite penetrating he said so himself,

humming tunes as he walked

the sedimentary rocks at Salisbury Crags,

his grey shales tilted between Dunbar and Eyemouth.

Would he have the same turn of tune if he saw your rocks, Hank?

Would Hutton's heart beat the same rhythm for Newfoundland as it did his Scotland? He'd walk your Tablelands

humming Harry Hibbs' tunes just for effect, we know that now ...

he would see why we call this home

he would understand our love of rock and water

know why we caress each stone each pounding wave,

know why we are who we are...

like Robbie Burns who was "bred to the plow" we are born of this place, of relentless coastline and this heroic sea...

So now, over 200 years later, the gentleman fiddler from the Southside calls out to the world, calls out across Iapetus echoing off Hutton's Unconformity, booming off his granite grave

"Get up, Jim, and get over here ...

I got somethin' to show ya' and y'er not gonna' believe it!"

Des Walsh February 19, 2007 